\title{
lodine Status of Schoolchildren in Hungary: Improvement a Decade on
}

\author{
Ferenc Péter ${ }^{\mathrm{a}}$ Jan Podobab Ágota Muzsnai ${ }^{\mathrm{a}}$ \\ a Pediatric Endocrinology Unit, St. John's Hospital and United Hospitals of North-Buda, Buda Children's Hospital, \\ Budapest, and ${ }^{b}$ Department of Endocrinology, Slovak Medical University and St. Elizabeth Cancer Institute, \\ Bratislava, Slovakia
}

Dear Editor,

Insufficient iodine nutrition is still an existing problem in some European countries [1]; however, the incidence of iodine deficiency has decreased during the last few decades. To prevent endemic goiter, a national iodization program was introduced in Hungary in 1949, but this program was never completed $[2,3]$. Therefore, Hungary has been classified officially until now as a mild iodine-deficient country mainly on the basis of earlier data $[1,4]$.

At the time of the European ThyroMobil program, which took place in 12 European countries including Hungary, the goiter rate according to the thyroid volume as well as the urinary iodine concentrations (UICs) were considered the main indicators of iodine nutrition [4]. After a revision of this recommendation, it was proposed to use UIC as the primary indicator of the impact of iodine supplementation, and the household coverage with iodized salt as a secondary indicator [5]. Three Hungarian cities (Csákvár in West Hungary, Budapest in the middle of the country, and Szolnok in East Hungary) were selected to participate in the European ThyroMobil program (1994), and the survey was repeated in the same cities a decade later (2005). Thyroid ultrasound was performed in schoolchildren (ranging from 6 to 14 years of age), and spot urine specimens were collected (table 1). A mobile unit equipped with an ultrasound device and refrigerator for the storage of collected urine samples visited these three Hungarian cities. The UIC of the Hungarian samples was determined the first time independently in a central laboratory in Brussels [4] and in our local laboratory according to Wawschinek et al. [6]; both methods are based on a colorimetric ceric ion arsenious acid wet ash procedure. The correlation coefficient proved to be 0.91 between the two parallel measurements. Four WHO reference samples were used during these surveys to qualify the local method and these showed excellent correlation $(r=0.997)$.

The characteristics of the UICs are summarized in table 2 . Two Hungarian cities (Csákvár and Budapest) proved to be mild iodine-deficient areas in the first survey according to the results of all parameters $(>20 \%$ were $<50 \mu \mathrm{g} / \mathrm{l} ;>50 \%$ were $<100$ $\mu \mathrm{g} / \mathrm{l}$; the median values were $<100 \mu \mathrm{g} / \mathrm{l}$ ). Each individual value showed a significant improvement in the second survey (unpaired t test, $\mathrm{p}<0.001$ ) suggesting a normalization of iodine intake in the subsequent decade in these areas. In addition, the proportion of UICs $>300 \mu \mathrm{g} / \mathrm{l}$ increased significantly: Csákvár $=30.5 \%$, Budapest $=$ $54.3 \%$, and Szolnok $=42.2 \%$.

The thyroid volume results of the European ThyroMobil study were compared to the reference values of the iodine-supplied schoolchildren gained in the ThyroMobil survey [4]. Goiter was defined as a thyroid enlargement above the upper limit of normal volume (ml) according to the age and sex. Only Csákvár proved to be a mild iodine-deficient area (prevalence of goiter in Csákvár $=8 \%$, Budapest $=4 \%$, and Szolnok $=3 \%$ ) in 1994 , but goiter prevalence decreased to $<5 \%$ in each location (Csákvár $=1 \%$, Budapest $=1 \%$, and Szolnok = $0 \%$ ) by 2005 (table 2 ).

The aim of this letter is to present the significant improvement of the iodine supply in the same three cities in the decade following the ThyroMobil survey by using the same standard methods to determine the UIC and the thyroid volume measured by ultrasonography in schoolchildren. The median urinary iodine values in the previously iodine-deficient cities increased considerably above $100 \mu \mathrm{g} / \mathrm{l}$ by 2005 (table 2). Somewhat surprisingly, quite a high proportion of individual UIC values passed $300 \mu \mathrm{g} / \mathrm{l}$. A possible explanation for this is the particularly high salt content of Hungarian food (10-15 g/day intake). The importance of achieving an optimal increase in iodine and decrease in salt intake as a public health problem was gradually more acknowledged at the end of the last century. There are ongoing initiatives to decrease salt consumption by the public health authorities, so a decrease in the relatively high proportion of excessive iodine intake (UIC $>300 \mu \mathrm{g} / \mathrm{l}$ ) may be expected in the future.

Interpreting the thyroid volume data is not as simple. The results from the ThyroMobil study, which documents data of iodine-replete children from 4 European

\begin{tabular}{ll}
\hline KARGER 125\% & $\begin{array}{l}\text { (2) } 2015 \text { European Thyroid Association } \\
\text { Published by S. Karger AG, Basel } \\
2235-0640 / 15 / 0041-0071 \$ 39.50 / 0\end{array}$ \\
$\begin{array}{l}\text { E-Mail karger@karger.com } \\
\text { www.karger.com/etj }\end{array}$ &
\end{tabular}

Ferenc Péter, MD, DSc

Pediatric Endocrinology Unit, St. John's Hospital and United Hospitals of North-Buda Buda Children's Hospital, Bolyai utca 5-9 HU-1023 Budapest (Hungary)

E-Mail ferenc.dr.peter@gmail.com 
Table 1. Number of children investigated in each city in 1994 and in 2005

\begin{tabular}{llllll}
\hline \multirow{2}{*}{ City } & \multicolumn{2}{l}{ Thyroid volume } & & \multicolumn{2}{l}{ Urinary iodine } \\
\cline { 2 - 3 } & 1994 & 2005 & & 1994 & 2005 \\
\hline Csákvár & 105 & 82 & & 105 & 82 \\
Budapest & 134 & 126 & & 68 & 92 \\
Szolnok & 152 & 163 & & 71 & 161 \\
\hline Total & 391 & 371 & & 244 & 335 \\
\hline
\end{tabular}

Table 2. UIC and prevalence of goiter results

\begin{tabular}{lccc}
\hline & Csákvár & Budapest & Szolnok \\
\hline 1994 & & & \\
UIC $<50 \mu \mathrm{g} / \mathrm{l}, \%$ & $\mathbf{2 4 . 8}$ & $\mathbf{3 0 . 9}$ & 8.4 \\
$\mathrm{UIC}<100 \mu \mathrm{g} / \mathrm{l}, \%$ & $\mathbf{5 1 . 4}$ & $\mathbf{6 7 . 6}$ & 39.4 \\
Median UIC, $\mu \mathrm{g} / \mathrm{l}$ & $\mathbf{5 2 . 0}$ & $\mathbf{7 2 . 5}$ & 114.5 \\
Goiter, $\%$ & $\mathbf{8}$ & 4 & 3 \\
\hline 2005 & & & \\
UIC $<50 \mu \mathrm{g} / \mathrm{l}, \%$ & 1.2 & 3.3 & 0.0 \\
UIC $<100 \mu \mathrm{g} / \mathrm{l}, \%$ & 13.4 & 9.8 & 10.6 \\
Median UIC, $\mu \mathrm{g} / \mathrm{l}$ & 183.0 & 249.5 & 239.0 \\
Goiter, $\%$ & 1 & 1 & 0
\end{tabular}

Bold type represents values outside of the normal range.

countries, were recommended as new reference values [4]. These reference values were later reevaluated by Zimmermann et al. [7]. The latest opinion by Swedish authors claims that 'the reliability of thyroid volume determination by ultrasound is limited' with intra- and interindividual variability at $\sim 15 \%$ [8]. In our case there is no reason to change the reference values because we used the same measuring conditions in our comparative studies. Every measurement was carried out by the same specialist (J.P.) in both Hungarian surveys (1994 and 2005), as well as the European ThyroMobil study [4], thus eliminating the possibility of interobserver error. The results, showing a definite decrease in the prevalence of goiter, were in agreement with the changes in the UIC.

One of the main markers for monitoring iodine intake in industrialized countries is the proportion of households using adequately iodized salt (universal salt iodization $=$ USI) with the target of $>90 \%$ of households. Unfortunately, the Hungarian national salt iodization program has not progressed beyond the initial decision phase in the last decade. In spite of this, recently the proportion of households using iodized salt has increased from $25-30 \%$ [3] to over $80 \%$ at least in these areas [9].

Increasing general knowledge through media can have an important role in the improvement of iodine nutrition. The $\mathrm{Na}$ tional Committee for IDD organized a 1-day meeting on iodine nutrition supported by the ICCIDD West Central Europe Region and local staff of the UNICEF in 2002. Besides the scientific meeting (invited speaker was the deputy regional coordinator, Prof. P. Vitti), several programs were organized also for the media. This successful initiative remained a prominent topic and discussed in the press, TV, radio, etc., for several months after the program. Similar Czech experiences were published [10].

This is the first observation of the elimination of iodine deficiency according to UIC values and thyroid volumes measured by ultrasonography in some areas of Hungary during the last decade. Further public health strategies (e.g. surveys including more vulnerable populations developing appropriate messages to the public, monitoring of salt, etc.) are still required to develop and sustain the improving iodine status in Hungary.

\section{Disclosure Statement}

The authors have nothing to disclose.

\section{References}

1 Lazarus JH: Iodine status in Europe in 2014. Eur Thyroid J 2014;3:3-6.

-2 Sós J, Szabó G, Raksányi Á: Endemic goiter and its prevention in Hungary. Bull World Health Organ 1956;15:317-327.

-3 Péter F: Status of iodine nutrition in Hungary; in Delange F, Dunn JT, Glinoer D (eds): Iodine Deficiency in Europe. New York, Plenum Press, 1993, pp 377-382.

4 Delange F, Benker G, Caron Ph, Eber O, Ott W, Péter F, Podoba J, Simescu M, Szybinsky Z, Vertongen F, Vitti P, Wiersinga W, Zamrazil V: Thyroid volume and urinary iodine in European schoolchildren: standardization of values for assessment of iodine deficiency. Eur J Endocrinol 1997;136:180-187.
5 WHO/UNICEF/ICCIDD: Assessment of Iodine Deficiency Disorders and Monitoring Their Elimination. A Guide for Programme Managers. Geneva, WHO Press, 2007.

6 Wawschinek O, Eber O, Petek W, Wakonig P, Gürakar A: Bestimmung der Harnjodausscheidung mittels einer modifizierten Cer-Arsenitmethode. Berichte ÖGKC 1985;8:13-15.

7 Zimmermann MB, Hess SY, Molinari L, De Benoist B, Delange F, Braverman LE, Fujieda K, Ito Y, Jooste PL, Moosa K, Pearce EN, Pretell EA, Shishiba Y: New reference values for thyroid volume by ultrasound in iodine-sufficient schoolchildren: a World Health Organization/Nutrition for Health and Development Iodine Deficiency Study Group Report. Am J Clin Nutr 2004;79:231-237.
8 Filipsson Nyström H, Andersson M, Berg G, Eggertsen R, Gramatkowski E, Hansson M, Hulthén L, Milakovic M, Nyström E: Thyroid volume in Swedish school children: a national, stratified, population-based survey. Eur J Clin Nutr 2010;64:1289-1295.

9 Péter F, Podoba J, Muzsnai Á, Kozma A, Gimesi A: Iodine nutrition of schoolchildren studied by 'ThyroMobil' model (1994-2005) (in Hungarian). Gyermekgyógyászat 2008;59: 177-181.

10 Zamrazil V, Bilek R, Cerovská J, Delange F: The elimination of iodine deficiency in the Czech Republic: the steps toward success. Thyroid 2004;14:49-56. 